\title{
Immunization by subcutaneous implants of polyester-polyurethane sponges coupled with antigen
}

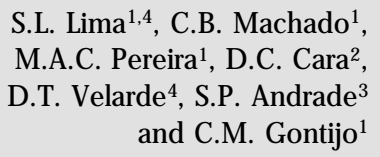

S.L. Lima ${ }^{1,4}$, C.B. Machado ${ }^{1}$, M.A.C. Pereira ${ }^{1}$, D.C. Cara ${ }^{2}$, D.T. Velarde ${ }^{4}$, S.P. Andrade ${ }^{3}$ and C.M. Gontijo ${ }^{1}$

\author{
Departamentos de ${ }^{1}$ Bioquímica e Imunologia, ${ }^{2}$ Patologia and \\ ${ }^{3}$ Fisiologia, Instituto de Ciências Biológicas, \\ Universidade Federal de Minas Gerais, Belo Horizonte, MG, Brasil \\ ${ }^{4}$ Fundação Ezequiel Dias, Belo Horizonte, MG, Brasil
}

\section{Correspondence \\ C.M. Gontijo \\ Departamento de Bioquímica e \\ Imunologia, ICB, UFM G \\ Caixa Postal 486 \\ 30161-970 Belo Horizonte, MG \\ Brasil \\ Fax: +55-31-441-5963 \\ E-mail: cgontijo@mono.icb.ufmg.br \\ Presented at the XIII Annual Meeting of the Federação de Sociedades de Biologia Experimental, Caxambu, MG, Brasil, August 26-29, 1998. \\ Research supported by FAPEMIG (No. 2295/96) and PRPq-Fundep- UFM G (No. 2913/33). C.B. Machado is supported by PRO BIC scholarship program (FAPEMIG).}

Received April 9, 1998

Accepted January 13, 1999

\section{Abstract}

A new protocol is described for immunization of outbred Swiss mice. The procedure is based on subcutaneous implantation of antigencoupled polyester-polyurethane sponges cut into disks of $10 \mathrm{~mm}$ in diameter vs $2 \mathrm{~mm}$ in thickness. Antigen coupling was performed by overnight incubation of the sponge with a solution of ovalbumin (Ova) $(2 \mathrm{mg} / \mathrm{ml})$ diluted in sodium carbonate buffer, $\mathrm{pH}$ 9.6. The amount of ovalbumin that was taken up by the sponge was between 71.4 to 82.5 $\mu \mathrm{g}$. This was estimated by comparing the Ova absorbance at $280 \mathrm{~nm}$ in coating buffer solutions before and after incubation. To compare the efficiency of the proposed method, experimental groups immunized with the antigen in the presence of adjuvants $\left(10 \mu \mathrm{g}\right.$ in $\mathrm{Al}(\mathrm{OH})_{3}$ or 100 $\mu \mathrm{g}$ in complete Freund's adjuvant (CFA)) were run in parallel. The data obtained after the 3rd week of immunization indicate that both cellular and humoral immune responses were achieved. These were assayed by antigen-induced footpad swelling and ELISA (specific antibodies), respectively. The levels of both immune responses elicited were similar to the responses observed in mice immunized with ovalbumin in the presence of $\mathrm{Al}(\mathrm{OH})_{3}$. The method might represent an advantage when immunizing with pathogenic antigens. Preliminary experiments have suggested that the antigen remains immobilized or bound to the sponge for a long period of time, since there is an increment on the cell population inside the sponges after boosting the animals. If so, the undesirable effects of immunization would be reduced.

There is a great interest in the development of new methods for immunizing experimental animals with lethal antigens such as toxins and/or venoms in order to obtain specific immune sera for medical purposes. The use of adjuvants such aluminum hydroxide $\left(\mathrm{Al}(\mathrm{OH})_{3}\right)$ and complete Freund's adjuvant (CFA) in schemes of immunization has been
Key words
- Sponge
- Implant
- Immunization
- Vaccine
$\ldots \ldots \ldots \ldots \ldots \ldots \ldots \ldots$ extensively studied and defined in order to reach maximum antibody production as well as minimal damage to the animal and antigen loss. CFA is considered to be a potent adjuvant and has proved to be useful for the production of horse antisera, although it may cause undesirable side effects. Animals submitted to immunization with this adjuvant 
for a long period of time often show skin lesions followed by a reduction in their ability to produce antibodies $(1,2) \cdot \mathrm{Al}(\mathrm{OH})_{3}$, which does not induce these effects, is not as potent an adjuvant as CFA (3). Protein iodination (4) and encapsulation of the antigen into liposomes $(5,6)$ are examples of methods that have been proposed to avoid these problems. These methods reduce toxicity but not immunogenicity. However, losses may occur and accidents have been reported (4-7).

Looking for an alternative way of immunizing, we became interested in an experimental model developed for studying angiogenesis in rats $(8)$ and mice $(9,10)$. In this model, subcutaneous implants of polyesterpolyurethane sponges are performed in the dorsal region of the animals where they act as a matrix for the development of blood vessels and connective tissue. These implants stimulate an inflammatory infiltrate rich in mononuclear cells by the end of the first week. Antigens, on the other hand, can be associated with inorganic materials such as polystyrene plates (Nunc, Copenhagen, Denmark) that are used for ELISA reactions. Using a similar protocol, polyester-polyurethane sponges were treated with chicken egg albumin (ovalbumin - Ova) grade III (Sigma Chemical Co., St. Louis, MO, USA) in sodium carbonate buffer, $\mathrm{pH} 9.6$ (coating buffer), and then implanted into experimental mice. Ova is not a pathogenic antigen and its immunogenicity is not considered to be high. Polyester-polyurethane sponges were cut into disks (10 $\mathrm{mm}$ in diameter $v s 2 \mathrm{~mm}$ in thickness), treated with $70 \%$ ethanol for $1 \mathrm{~h}$ and then boiled in distilled water for $30 \mathrm{~min}$. The sponges were then dried under sterile conditions and immersed in coating buffer $(1 \mathrm{ml} /$ sponge) containing Ova at different concentrations $(0.2,2$ and $20 \mathrm{mg} / \mathrm{ml})$, centrifuged to assure that all the internal surface was in contact with the solution and then incubated overnight at $4^{\circ} \mathrm{C}$. The sponges were washed 3 times in sterile PBS before being subcuta- neously implanted into 6-8-week-old outbred female Swiss mice. We estimated the incorporation of 71.4-82.5 $\mu \mathrm{g}$ of Ova/sponge by comparing the Ova absorbance at $280 \mathrm{~nm}$ in coating buffer solutions before and after incubation.

For positive control of immunization, mice were injected either intraperitoneally (ip) with $200 \mu \mathrm{l}$ of saline containing $10 \mu \mathrm{g}$ Ova mixed with $1 \mathrm{mg} \mathrm{Al}(\mathrm{OH})_{3}$ or subcutaneously (sc) with $40 \mu \mathrm{l}$ of saline containing 100 $\mu \mathrm{g}$ Ova mixed with CFA (Sigma). Negative control mice were implanted with a sponge that was not pretreated with Ova, or were injected as described above, but without the antigen. In some experiments, mice were boosted 3 weeks later with $10 \mu \mathrm{g}$ Ova in 200 $\mu \mathrm{l}$ saline, ip. Blood samples were collected weekly from the tail of mice and diluted in PBS (1:3). After clotting and centrifugation, the supernatants were collected and stored at $-20^{\circ} \mathrm{C}$.

Anti-Ova antibodies were assayed by ELISA. Briefly, polystyrene plates (Nunc) were coated overnight at $4^{\circ} \mathrm{C}$ with $2 \mu \mathrm{g}$ Ova diluted in $100 \mu \mathrm{l}$ coating buffer per well, washed with saline containing $0.05 \%(\mathrm{w} / \mathrm{v})$ Tween-20, saturated with $0.25 \%(\mathrm{w} / \mathrm{v})$ casein in PBS, washed again and then coated with serial dilution of mouse antiserum starting at 1:100. After $1 \mathrm{~h}$ at $37^{\circ} \mathrm{C}$, plates were washed, incubated for $1 \mathrm{~h}$ at $37^{\circ} \mathrm{C}$ with peroxidaseconjugated goat anti-mouse globulin antiserum (Southern Biotechnology, Birmingham, $\mathrm{AL}$ ), washed and developed by the addition of $\mathrm{H}_{2} \mathrm{O}_{2}$ and ortho-phenylene-diamine (OPD; Sigma). The reaction was interrupted at 10 min by the addition of $\mathrm{H}_{2} \mathrm{SO}_{4}$ at $1 / 20$ dilution and absorbance was read at $492 \mathrm{~nm}$ in EIAreader (Biorad, Hercules, CA, USA). The absorbance values obtained in the assays are reported as a score (ELISA*) which represents the mean \pm SEM $(N=5-7)$ of the sums of absorbance values of ELISA run with serum dilutions from $1 / 100$ to $1 / 25600$. The highest absorbance values obtained at 1/100 dilution were in the linear response region 
and the values obtained at $1 / 25600$ dilution always reached the blank level. This way of reporting the results is equivalent to reporting titration curves or selecting the absorbance at one particular serum dilution as representative. The significance of the difference between experimental and control groups was assessed by the Kruskal-Wallis test for nonparametric data. Positive and negative control samples were run on every plate. A mouse was considered to be immunized if its ELISA* score was higher than the mean of normal control mice plus 3 times the SD.

The kinetics of anti-Ova antibody production for a period of 8 weeks is shown in Figure 1A for mice immunized with implants of sponges containing Ova. Positive control groups were prepared by immunizing mice with the antigen in the presence of adjuvants ( $\mathrm{CFA}$ and $\left.\mathrm{Al}(\mathrm{OH})_{3}\right)$. Another group received $10 \mu \mathrm{g}$ of Ova in saline, ip, without adjuvant. No antibody was produced by the animals of this last group, which actually exhibited the same profile as negative nonimmunized control groups (data not shown). Although requiring a longer time, spongeimplanted mice produced specific antibodies at the same level as those immunized with $\mathrm{Al}(\mathrm{OH})_{3}$. When the activity of CFA and $\mathrm{Al}(\mathrm{OH})_{3}$ as adjuvants is compared, we observe that a higher level of antibody production was obtained with CFA. This may be explained by the difference in the amount of Ova injected. Figure 1B shows the profiles of the groups when animals received $10 \mu \mathrm{g}$ of Ova in saline, ip, as a booster on day 21. One week after the booster, sponge-implanted mice reached the antibody level of the group immunized with $\mathrm{Al}(\mathrm{OH})_{3}$. The levels reached by these 2 groups in Figure 1B were higher than those observed in Figure 1A. On the other hand, with the exception of the first week after the booster (week 4), no difference was observed between the profiles of mice immunized with Ova in CFA as adjuvant, when primary and secondary responses were compared.

We also tested whether the implant of Ova-coated sponges also elicited a cellular immune response. As shown in Figure 2, we have compared this procedure between groups that were immunized with Ova diluted in saline with or without the presence of CFA, incomplete Freund's adjuvant (IFA) or $\mathrm{Al}(\mathrm{OH})_{3}$ as adjuvants. During the third week after implant or immunization, the groups were injected $s c$ with $30 \mu \mathrm{l}$ of a $2 \%$ aggregated Ova solution into the left footpad. The same volume of PBS was injected $s c$ into the right footpad as control (11). The data in Figure 2 are reported as the difference in thickness between footpads observed $48 \mathrm{~h}$ after injection. With the exception of the group immunized with Ova in the absence of adjuvants, in all other groups a significant increase of footpad thickness was observed. Differences $(\mathrm{P}<0.05)$ were ob-

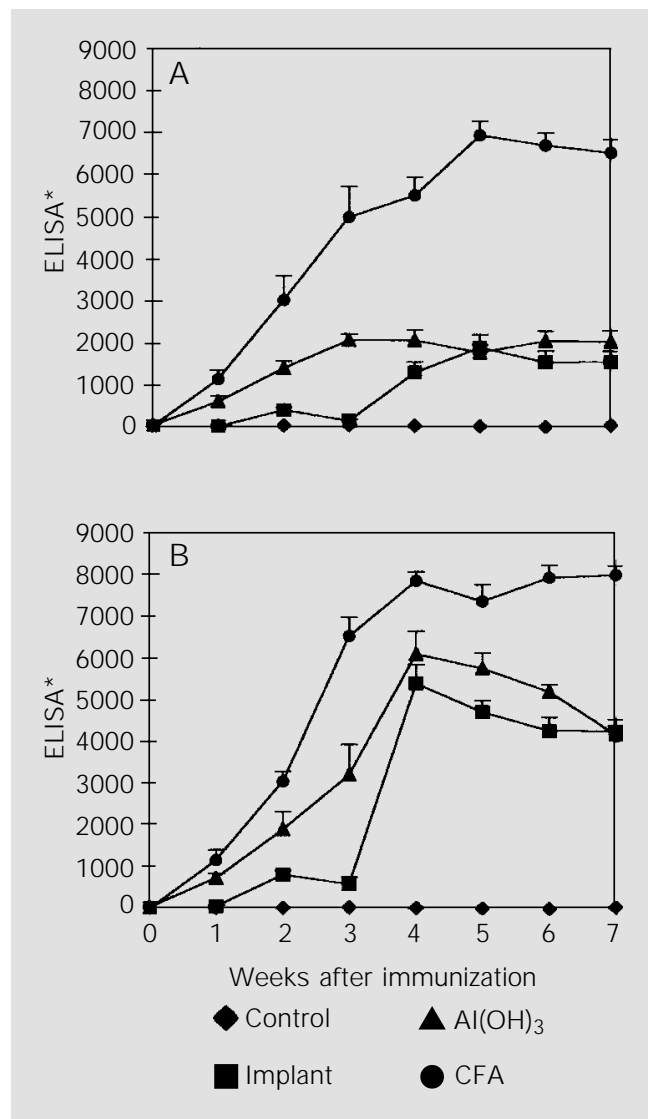

Figure 1 - Humoral immune responses elicited by Ova-conjugated implanted sponges. A, For the primary immune response, Swiss mice were immunized with Ova in $\mathrm{Al}(\mathrm{OH})_{3}(10 \mu \mathrm{g}$, ip) or in complete Freund's adjuvant (CFA) $(100 \mu \mathrm{g}, \mathrm{sc})$, or were implanted subcutaneously with Ova-coupled sponges. Controls were either injected with $10 \mu \mathrm{g}$ of Ova in saline, ip, or implanted with sponges treated without Ova. B, For the secondary immune response, the above protocol was repeated but mice received $10 \mu \mathrm{g}$ of Ova diluted in saline, ip, during week 3 as a booster. Anti-Ova antibodies were detected by ELISA. Data are reported as ELISA* score, which represents the mean \pm SEM (N = 5-7) of the sums of absorbance values from senum dilutions of $1 / 100-1 / 25600$. 


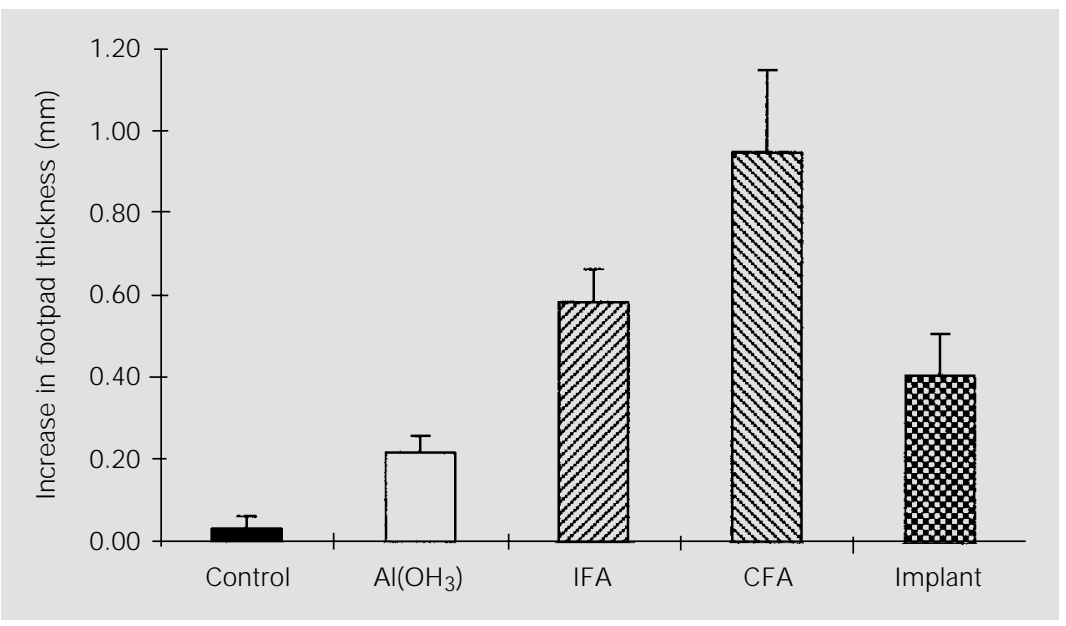

Figure 2 - Cellular immune response elicited by Ova-conjugated implanted sponges. Swiss mice were immunized with Ova in $\mathrm{Al}(\mathrm{OH})_{3}(10 \mu \mathrm{g}$, ip), complete Freund's adjuvant (CFA) $(100 \mu \mathrm{g}, \mathrm{sc})$ or incomplete Freund's adjuvant (IFA) $(100 \mu \mathrm{g}, \mathrm{sc})$, or were implanted subcutaneously with Ova-coupled sponges. Controls were either injected with $10 \mu \mathrm{g}$ of Ova in saline, ip, or implanted with sponges treated without Ova. During week 3, mice were injected subcutaneously with $30 \mu$ of either $2 \%$ aggregated Ova (left footpad) or PBS (right footpad). Data are reported as the difference in thickness (mean \pm SEM, $N=5-7$ ) between both footpads observed $48 \mathrm{~h}$ after injection.

served between the three groups immunized with adjuvants (CFA, IFA and $\left.\mathrm{Al}(\mathrm{OH})_{3}\right)$. No difference was observed between mice implanted with an Ova-treated sponge and those immunized with Ova in the presence of IFA or $\mathrm{Al}(\mathrm{OH})_{3}$ as adjuvants.

The subcutaneous implantation of an antigen-coated sponge provided an alternative method for immunization. Both humoral and cellular immune responses were achieved at levels similar to those obtained when $\mathrm{Al}(\mathrm{OH})_{3}$ was used as adjuvant. It is known that polyester-polyurethane sponge implants cause a granulomatous reaction characterized by an inflammatory infiltrate rich in polymorphonuclear cells, macrophages and giant cells around the trabeculae of the sponge matrix (9). A similar reaction is observed in granulomas formed when antigen is subcutaneously injected in the presence of $\mathrm{Al}(\mathrm{OH})_{3}$ (12). The similarity of our proposed method and the use of $\mathrm{Al}(\mathrm{OH})_{3}$ as adjuvant should be further analyzed. For instance, we are currently characterizing the isotypes that are formed when mice are implanted with antigen-coated sponges (13). It is known that, differently from CFA that usually elicits immune responses with a predominance of the $\mathrm{T}_{\mathrm{H}} 1$ subset of T-lymphocytes, $\mathrm{Al}(\mathrm{OH})_{3}$ is thought to elicit $\mathrm{T}_{\mathrm{H}} 2$-type immune responses (14).

Antigen delivery from the sponge is another fact that deserves attention. Preliminary data from histological studies indicate that antigen delivery from the sponge should be slow. Histological changes occur in sponges when mice are boosted, indicating that antigens are probably still present at the site after at least 3 weeks. This possibility is very attractive since the method could represent an alternative for fixing pathogenic antigens at a site, with the consequent reduction of toxic effects during immunization procedures.

\section{References}

1. Oropeza RM, Perez GC \& Manes SC (1972). Esquema modificado para la obtención de sueros antiofídicos. Revista de Investigación en Salud Pública, 32: 179-186.

2. Bolanos R \& Cerdas L (1978). The production and control of anti-venous sera. Developments in Biological Standardization, 41: 907-911.

3. Raw I, Guidolin R, Higashi HG \& Kelem EMA (1991). Antivenins in Brazil: preparation. In: Tu AT (Editor), Reptile Venoms and Toxins, Handbook of Natural Toxins. Marcel Dekker, New York.
4. Daniel JP, Heneine LGD, Tavares CAP, Nascimento MCS \& Heneine IF (1987). Generation of protective immune sera by Crotalus durissus terrificus venom detoxified by controlled iodination. Brazilian J ournal of Medical and Biological Research, 20: 713-720.

5. Freitas TV \& Frézard F (1997). Encapsulation of native crotoxin in liposomes: a safe approach for the production of antivenom and vaccination against Crotalus durissus terrificus venom. Toxicon, 35: 91-100.

6. Chavez-Olortegui C, Ait-Amara D, Rochat H, Diniz CR \& Granier C (1991). In vivo protection against scorpions by liposomal immunization. Vaccine, 9: 713-720.

7. Freitas TV, Fortes-Dias CL, Diniz CR, Velarde DT \& Freitas CF (1991). Immunization of horses with Crotalus durissus terrificus (South American Rattlesnake) venom. A comparison of four different procedures. Brazilian J oumal of Medical and Biological Research, 24: 281-290.

8. Andrade SP, Fan TPD \& Lewis GP (1987). Quantitative in vivo studies on angiogenesis in a rat sponge model. British J oumal of Experimental Pathology, 68: 755-766.

9. Barros-Vieira LBG (1991). Modelo experi- 
mental para estudo da angiogênese em camundongos. Master's thesis, Departamento de Fisiologia, Universidade Federal de Minas Gerais, Belo Horizonte.

10. Andrade SP, Machado RDP, Teixeira AS, Belo AV, Tarso AM \& Beraldo WT (1997). Sponge-induced angiogenesis in mice and the pharmacological reactivity of the neovasculature quantified by a fluorimetric method. Microvascular Research, 54: 253261.

11. Titus RG \& Chiller J M (1981). A simple and effective method to assess murine delayed-type hypersensitivity to proteins. J ournal of Immunological Method, 45: 6578.

12. Gupta RK, Rost BE, Relyveld E \& Siber GR (1995). Adjuvant properties of aluminum and calcium compounds. In: Powell MF \& Newman MJ (Editors), Vaccine Design: The Subunit and Adjuvant Approach. Plenum Publishing Corporation, New York.

13. Gontijo CM, Lima SL, Cara DC, Velarde DT \& Andrade SP (1998). Subcutaneous implants of polyester-polyurethane sponges coupled with antigen as a model for immunizing experimental animals. In: Talwar GP, Nath I, Ganguly NK \& Rao KVS (Editors), Proceedings of the 10th International Congress of Immunology, New Delhi, India, November 1-6, 1998. Monduzzi Editore, Bologna, 1415-1419.

14. Vogel FR (1995). The role of adjuvants in retroviral vaccines. International J ournal of Immunopharmacology, 17: 85-90. 
The Pew Latin American Fellows Program in the Biomedical Sciences is providing support for young scientists from Latin America for post-doctoral training in the United States.

Ten Fellows will be selected in 1999. An award of $\$ 50,000$ will be provided as a salary stipend for the fellow during the period of training (2 years) and will be administered by the sponsoring U.S. institution. The sponsoring institution is expected to supplement the stipend with at least $\$ 5,000$ a year and provide medical benefits for the fellow. Following the two year fellowship, the Program will issue an additional $\$ 35,000$ award to the sponsoring institution to purchase equipment and supplies for the fellow to establish a laboratory in his or her home country.

Applicants must have held a Ph.D. and/or M.D. degrees, or equivalent, for no more than five years as of July 1, 1999. Strong preference will be given to those applicants with no previous postdoctoral training outside of their home country. Applicants are not required to have a commitment of a position and laboratory space after the fellowship. However, applicants must submit a written statement of intent to return to Latin America. Fellows must have a confirmed position and laboratory space in their home country by the end of the fellowship period in order to obtain the $\$ 35,000$ portion of the award.

Fellows will be selected on the basis of their promise as outstanding investigators, as well as the scientific merit of their research proposal, their record of training and how well their interests coincide with the laboratory of their sponsor in the U nited States. If potential applicants need assistance with the identification of an appropriate sponsoring laboratory in the United States, they may contact the Program O ffice before August 1, 1999. The Program will accept applicants from Mexico, Central and South America. Applications may be obtained from the Regional Committee contact listed here for your country or from our website at http://futurehealth.ucsf.edu/pewlatin.html

The application deadline is 0 ctober 1,1999 . W inners will be notified in April 2000 and the fellowship should begin no later than August 2000.

\section{Argentina}

Israel Algranati

Instituto de Investigaciones Bioquímicas Fundación Campomar Av. Patricias Argentinas, 435 1405 Buenos Aires Tel: 863-4018/Fax: 865-2246 e-mail: algra@ iris.iib.uba.ar

\section{Brasil}

Carlos Eduardo Rocha-Miranda Vice President, Academia Brasileira de Ciências Rua Anfilófio de Carvalho, 29, 30 andar 20030-060 Rio de Janeiro, RJ, Brasil

Tel.: 220-4794/Fax: 240-4695 E-mail: cerm@abc.org.br

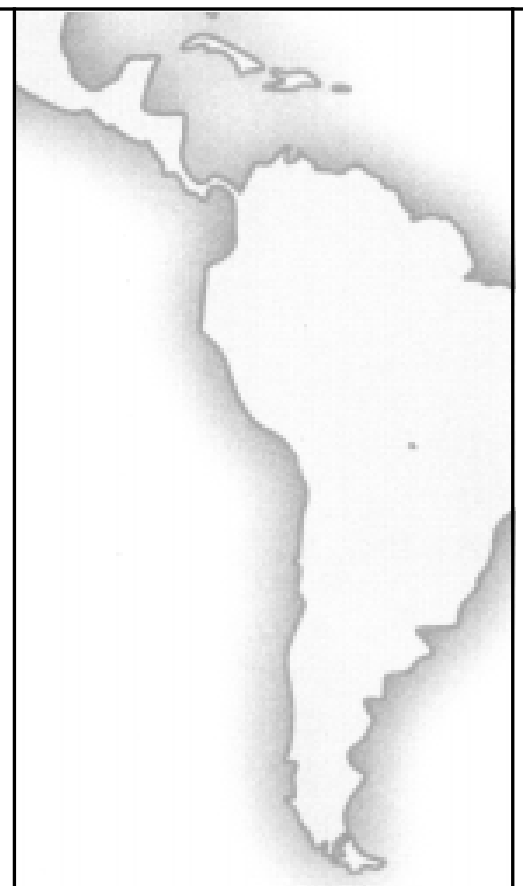

\section{Mexico}

Hugo Aréchiga

Facultad de Medicina UNAM

Ciudad Universitaria 04510

Mexico, D.F.

Tel: 622-0725/Fax: 550-8859

e-mail: arechiga@ servidor.unam.mx

\section{Chile}

Manuel A. Kukuljan, Ph.D.

Universidad de Chile

Departamento de Fisiologia y Biofisica

Casilla 70005 Santiago 7, Chile

Tel: 2-678-6310/Fax: 2-777-6916

e-mail: kukuljan@ bitmed.med.uchile.cl

\section{All other countries}

Silvia Montano de Jiménez

The Pew Latin American Fellows Program

3333 California Street, Suite 410

San Francisco, CA 94118

Tel: 415-476-5116/Fax: 415-476-4113

e-mail: montano@ itsa.ucsf.edu 